\title{
ROLE OF A COMBINED SOLUBLE INTERLEUKINE-2 RECEPTOR ALPHA (SIL-R2 $\alpha$ ) AND CA-125 SERUM MARKER ASSAY FOR DETECTION OF OVARIAN CANCER
}

\author{
Ronalds Mačuks*, leva Baidekalna*, Inta Nuķe ${ }^{\star *}$, and Simona Doniņa**, *** \\ * Rīga Stradiṇš University, Dzirciema iela 16, Rīga, LV-1007, LATVIA \\ E-mail: r.macuks@gmail.com \\ ** Latvian Oncology Centre, Rīga Eastern Clinical University Hospital, Hipokrāta iela 4, Rīga, LV-1038, LATVIA \\ *** Rīga Pauls Stradiṇš University, Augusts Kirhenšteins Institute of Microbiology and Virology, Rātsupītes iela 5, Rīga, LV-1067, LATVIA
}

Communicated by Modra Murovska

\begin{abstract}
Detection of ovarian cancer can be improved using a combined diagnostic test consisting of Ca-125 and serum interleukine-2 receptor alpha (s/L-R2 $\alpha)$ at a particular threshold. The objective of the study was to evaluate the accuracy of a diagnostic marker assay that combined Ca-125 and serum interleukine-2 receptor alpha. A case-control study of 38 patients with ovarian cancer, 40 patients with benign ovarian diseases and 31 age-matched healthy controls was designed. Ca-125 and slL-2R $\alpha$ were detected in patients' serum by standardized chemiluminescent immunometric assays. For Ca-125, a standard cutoff level of $21 \mathrm{U} / \mathrm{ml}$ was applied and for sIL-R2 $\alpha$ - two cutoff levels were calculated from women included in the control group - one as a mean concentration and the other as an upper limit of a 95\% confidence interval. Mean serum concentrations among ovarian cancer patients for CA125 and s/L-2R $\alpha$ were $265.9 \pm 40.2 \mathrm{U} / \mathrm{ml}$ and $651.0 \pm 50.5 \mathrm{U} / \mathrm{ml}$, respectively. The upper limit of the 95\% confidence interval for a healthy control group of women was $304.5 \mathrm{U} / \mathrm{ml}$ for sIL-2R $\alpha$. Sensitivity and specificity of $89.4 \%$ and 85.9\% was achieved when CA125 was combined together with sIL-2R $\alpha$ at a threshold of $304.5 \mathrm{U} / \mathrm{ml}$ with the condition that both markers are elevated. Sensitivity and specificity of $92.5 \%$ and $88.4 \%$ was observed when both biomarkers were applied to menopausal women. Serum sIL-2R $\alpha$ in combination with CA125 can be used as a differential diagnostic test for ovarian cancer at a specific threshold, especially among menopausal women.
\end{abstract}

Key words: ovarian cancer, Ca125, interleukine-2 receptor alpha, screening, diagnostics.

\section{INTRODUCTION}

A variety of modalities have been investigated to differentiate the primary nature of adnexial masses (either benign or malignant); however, none of the current facilities has been shown to have adequate sensitivity or specificity to be accepted as a good indicator of malignant potential of ovarian diseases.

Interleukin-2 is a serum polypeptide, produced after activation of $\mathrm{T}$ lymphocytes by interaction of specific T-cell antigen receptors with antigen presented by the major histocompatibility complex (Altman et al., 1990). Interleukin-2 is one of the most important cytokines transferring signals for $\mathrm{T}$ cells and natural killers, and is involved also in other immunological reactions (Smith, 1988). Signal transferred by interleukin- 2 to $\mathrm{T}$ cells ensures proliferation and differentiation of effector cells (Mills et al., 1991; Waldmann, 1991).
IL-2 receptor is a complex of three non-covalently associated polypeptide chains: IL-2R $\alpha$ (CD25), IL-2R $\beta$ (CD122), and IL-2R $\gamma$. IL-2R $\alpha$ appears on the surface only after activation of T cells, while IL-2R $\beta$ and IL-2R $\gamma$ are expressed permanently (Waldmann, 1991). IL-2R $\alpha$ then is released into the blood stream only after cell proliferation begins (Rubin et al., 1985; 1990). The appearance of sIL-2R $\alpha$ in blood is thought to be one of the most accurate predictors of lymphocyte activation (Rubin et al., 1990). High levels of sIL-2R $\alpha$ have been found in sera from patients with different types of tumours (Brunetti et al., 1999; Lissoni et al., 1990; Rubin et al., 1990).

Barton et al. was the first one who published results on serum and ascitic levels of sIL-2R $\alpha$ and their correlation with CA-125 levels (Barton et al., 1993). Almost at the same time, a similar study was conducted by Owens et al.; these results were in accordance with the previously published data. Both studies compared serum and ascitic concentra- 
tions of sIL-2R $\alpha$ and $\mathrm{Ca} 125$ and concluded that the ascitic concentration of sIL-2R $\alpha$ was significantly higher than in sera (Barton et al., 1993; Owens et al., 1993). Later data was published on concentrations of sIL-2R $\alpha$ in sera, ascitic fluid and within the cystic fluid. The study showed that sIL-2R $\alpha$ values were higher in ascitis compared with those in sera, and the concentrations in sera and cyst fluids were comparable. They also noted that the assessment of serum sIL-2R $\alpha$ levels showed potential complementary value to CA125 for the detection of early stage ovarian carcinoma, but a $9 \%$ false positive rate limited the significance of cumulative value for a combination of these circulating markers (Sedlaczek et al., 2002).

Gebauer et al. (1999) established a cutoff level at the 95th percentile of the sIL-2R $\alpha$ concentration distributed in patients with benign diseases at $1200 \mathrm{U} / \mathrm{ml}$. According to their results, $35 \%$ of ovarian cancer patients had elevated concentrations, and concentrations of sIL-2R $\alpha$ increased with FIGO stage. Moreover, FIGO-stage III patients with highly elevated sIL-2R $\alpha$ concentrations tended to have better prognosis than those with sIL-2R $\alpha$ levels within the normal range (Gebauer et al., 1999). This may indicate the role of the immune system as well as sIL-2R $\alpha$ in the process of carcinogenesis, which was confirmed in another study in which patients with higher pretreatment serum sIL-2R $\alpha$ levels (more than $1200 \mathrm{U} / \mathrm{ml}$ ) were found to have longer survival $(P<0.02)$, possibly explained by the presence of activated lymphocytes and a better immune surveillance (Pavlidis et al., 1995).

In the literature there is a gap of approximately ten years in publications about sIL-2R $\alpha$ in ovarian cancer patients, but recently sIL-2R $\alpha$ has been investigated as a prognostic marker in the case of head and neck cancer (Meyer et al., 2010), soft tissue sarcomas (Bien et al., 2010) in patients with Non-Hodgkin's lymphomas (Jo et al., 2010) and there is a lately published article in which ovarian cancer stage was associated with tryptophan degradation and a subsequent strong correlation with sIL-2R $\alpha$ was observed (Sperner-Unterweger et al., 2011).

Currently, a novel approaches using biomarker combinations in cancer diagnostics are being developed; therefore, we consider that the diagnostic abilities of sIL-2R $\alpha$ in combination with other markers can contribute to improved ovarian cancer diagnostics.

The aim of this study was to evaluate whether a diagnostic test consisting of serum soluble interleukine- 2 receptor alpha at particular cutoff levels improves ovarian cancer detection when used in combination with ovarian cancer antigen CA125, to test the previously established cutoff levels, and to search for possible correlations of these two antigens.

\section{MATERIAL AND METHODS}

A case-control study was conducted, which involved 109 women -38 patients with ovarian cancer in the $1^{\text {st }}$ study group, 40 patients with benign ovarian diseases in the $2^{\text {nd }}$ study group, and 31 age-matched healthy controls. All patients were observed at our hospital between January and December 2009. In the $1^{\text {st }}$ study group there were six patients with stage I/II and 32 patients with stage III/IV ovarian cancers. Tumour differentiation was as follows: eight cases with low grade, 14 cases with intermediate, and 16 cases with high-grade differentiation.

Women with severe co-morbidities, previous or co-existing malignancies other than epithelial ovarian carcinoma were excluded from the study. In the first study group only women with ovarian malignancies of epithelial origin were included. In the second study group four women with benign sex cord / stromal and four women with benign germ cell tumours also were included. The control group included women who visited a gynecologist for a routine prophylactic visit and who had undergone a transvaginal ultrasonographic investigation to verify that they did not have any gynecological disease or suspicious adnexial mass.

In the morning of the planned surgery day, serum samples from patients were collected into two Becton and Dickenson $6 \mathrm{ml}$ serum vaccutainers. The vaccutainers according to protocol were shaken 6-8 times, left 60 to 120 minutes for clot formation and centrifuged for 10 minutes at $1300 \mathrm{rpm}$. Then serum was aliquoted, divided and transferred into nine $0.5 \mathrm{ml}$ eppendorfs for storage at $-80{ }^{\circ} \mathrm{C}$. For the control group women, serum samples were taken after transvaginal ultrasonographic examination. The tumour markers CA125 and sIL-2R $\alpha$ levels were determined in patient serum by standard enzyme-labelled chemiluminescent immunometric assay using a Siemens analyzer Immulite 2000 and commercial kits with corresponding antibodies (Immulite Operator's Manual, 2002).

Sensitivity and specificity analysis for single biomarker and combinations of both were calculated in the Vassarstat website. Sensitivity and specificity for menopausal women was calculated separately. Other statistical calculations were performed using SPSS 17.0. To compare sensitivity and specificity of single and combined biomarker diagnostic tests, multivariate regression analysis was performed and a predictive model used to produce a ROC curve. Patients with concentrations of ovarian cancer antigen CA125 exceeding $1000 \mathrm{U} / \mathrm{ml}$ and sIL-2R $\alpha$ concentrations exceeding $1500 \mathrm{U} / \mathrm{ml}$ were excluded from descriptive analyses for mean biomarker concentration calculations in the groups and their comparison. Standard errors of the mean were calculated. To determine significant differences for variables in the study groups, an ANOVA test was performed and for correlation Pearson's correlation analysis was applied. Ovarian cancer antigens Ca125 and sIL-2R $\alpha$ were compared between groups also using the nonparametric MannWhitney test at different thresholds. For Ca125, a standard cutoff level of $21 \mathrm{U} / \mathrm{ml}$ was applied. Two cutoff levels for sIL-2R $\alpha$ were calculated from control group patients - one as a mean concentration of the group and the other as the upper limit of the $95 \%$ confidence interval for sIL-2R $\alpha$ concentration observed in the group. Microsoft Excel was used 
for data collection. Statistically significant correlations and differences between means were accepted at the level of 0.05. The study was approved by the Ethics Committee of Rīga Stradiňš University on 12 February 2009.

\section{RESULTS}

There were no age differences between study groups and the control group and there were similar proportions of menopausal women within each group (ANOVA; $P>0.05$ ). Both biomarker concentrations were significantly higher in ovarian cancer patient groups (ANOVA, One-way; $P<$ $0.001)$. Similarly, biomarker concentrations were higher in ovarian cancer patients even after exclusion of patients with extremely high biomarker concentrations (ANOVA, Oneway; $P<0.001$ for both markers).

There were 11 ovarian cancer patients from the same group with concentrations of CA125 ranging from 1394 to 10000 $\mathrm{U} / \mathrm{ml}$ and two patients with sIL-2R $\alpha$ concentrations of 3338 and $4716 \mathrm{U} / \mathrm{ml}$. After exclusion of patients with extremely high biomarker concentrations, mean serum concentrations of CA125 and sIL-2R $\alpha$ in the $1^{\text {st }}$ study group were $265.9 \pm$ $40.2 \mathrm{U} / \mathrm{ml}$ and $651.0 \pm 50.5 \mathrm{U} / \mathrm{ml}$, respectively.

The area under the curve was higher for CA125 than for sIL-2R $\alpha$ alone or in combination with Ca125 (Fig. 1). Addition of IL-2R $\alpha$ and CA125 decreased sensitivity of the diagnostic test at fixed specificities (Table 1). Sensitivity and specificity of $89.4 \%$ and $85.9 \%$ were achieved when CA125 was combined together with sIL-2R $\alpha$ at a threshold of $304.5 \mathrm{U} / \mathrm{ml}$, with the condition that both markers have to be elevated (Table 2). The highest sensitivity and specificity was observed when both biomarkers were elevated among women in menopause. There were $13.8 \%$ patients from the $1^{\text {st }}$ study group and $57.5 \%$ patients from the $2^{\text {nd }}$ study group with serum sIL-2R $\alpha$ concentrations below the threshold (349.5 U/ml, upper limit of 95\% CI) calculated from control

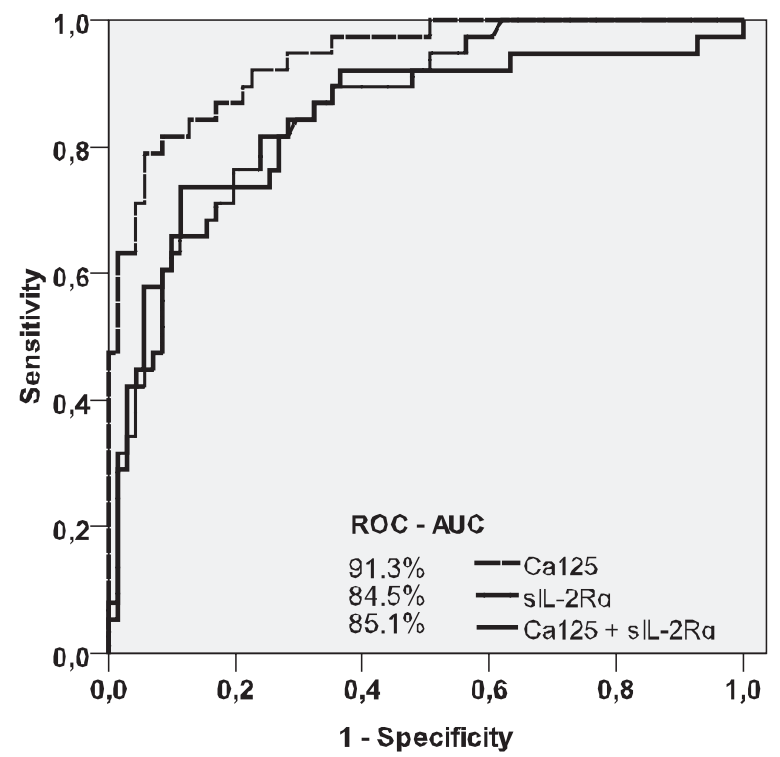

Fig. 1. Performance of the diagnostic test applied for pre- and postmenopausal women taken together. group patients. If the mean concentration of sIL- $2 \mathrm{R} \alpha$ derived from the control group is applied for discrimination of patients suffering from benign or malignant diseases, only $5.5 \%$ patients from the $1^{\text {st }}$ and $32.5 \%$ patients from $2^{\text {nd }}$ study group had serum sIL-2R $\alpha$ concentrations below the threshold, and $64.5 \%$ of women from the control group would be diagnosed as having ovarian cancer.

A stronger correlation between Ca125 and sIL-2R $\alpha$ serum concentrations was observed when the analysis was performed without patient exclusion with high serum biomarker concentrations (Pearson Correlation, 2-tailed; 32.3\% vs. $28.0 \%$ ); both of the obtained correlations were statistically significant (Fig. 2).

\section{DISCUSSION}

The serum concentration calculated as the threshold for sIL-2R $\alpha$ in our study was significantly lower than that proposed previously - 349.5 vs. $1200 \mathrm{U} / \mathrm{ml}$ (Gebauer et al.,

Table 1

PERFORMANCE OF SERUM CA125 AND SIL-2R $\alpha$ ALONE AND IN COMBINATION CALCULATED SEPARATELY FOR WOMEN IN MENOPAUSE AND FOR ALL WOMEN TAKEN TOGETHER AT FIXED SPECIFICITIES

\begin{tabular}{|c|c|c|c|c|}
\hline \multirow[t]{2}{*}{$\begin{array}{l}\text { Among all } \\
\text { women* }\end{array}$} & \multirow[t]{2}{*}{$\begin{array}{c}\text { AUC } \\
(95 \% \mathrm{CI})\end{array}$} & \multicolumn{3}{|c|}{$\begin{array}{c}\text { Cross validated sensitivity at } \\
\text { specificity }\end{array}$} \\
\hline & & $90 \%$ & $95 \%$ & $98 \%$ \\
\hline CA125 & $91.3 \%(85.5-97.2)$ & $74.1 \%$ & $59.3 \%$ & 48.1 \\
\hline sIL-2R $\alpha$ & $85.1 \%(77.8-92.4)$ & $61.1 \%$ & $38.9 \%$ & $27.8 \%$ \\
\hline CA125 + sIL-2R $\alpha$ & $84.5 \%(76.0-93.0)$ & $65.8 \%$ & $44.7 \%$ & $28.9 \%$ \\
\hline \multicolumn{5}{|c|}{ Among menopausal women* } \\
\hline CA125 & $95.3 \%(89.6-100.0)$ & $85.0 \%$ & $80.0 \%$ & $75.0 \%$ \\
\hline sIL-2R $\alpha$ & $85.0 \%(76.2-93.8)$ & $48.0 \%$ & $44.0 \%$ & $28.0 \%$ \\
\hline CA125 + sIL-2R $\alpha$ & $84.8 \%(73.8-95.7)$ & $74.1 \%$ & $70.4 \%$ & $48.1 \%$ \\
\hline
\end{tabular}

* Calculations are performed between $1^{\text {st }}$ study group and $2^{\text {nd }}$ study group taken together with control group

Table 2

DIAGNOSTIC PERFORMANCE OF SINGLE AND COMBINED BIOMARKER TEST CONSISTING OF SERUM CA125 AND SIL-2R $\alpha$ AT DIFFERENT THRESHOLDS

\begin{tabular}{|c|c|c|c|c|}
\hline \multirow[t]{2}{*}{$\begin{array}{c}\text { Biomarkers and } \\
\text { combinations }\end{array}$} & \multicolumn{2}{|c|}{ Among all women } & \multicolumn{2}{|c|}{$\begin{array}{l}\text { Among menopausal } \\
\text { women }\end{array}$} \\
\hline & sensitivity & specificity & sensitivity & specificity \\
\hline CA125(>21 U/ml) & $92.1 \%$ & $76.0 \%$ & $92.5 \%$ & $80.7 \%$ \\
\hline sIL-2R $\alpha(>304.5 \mathrm{U} / \mathrm{ml})$ & $94.7 \%$ & $46.4 \%$ & $96.2 \%$ & $42.3 \%$ \\
\hline $\mathrm{sIL}-2 \mathrm{R} \alpha(>349.5 \mathrm{U} / \mathrm{ml})$ & $86.8 \%$ & $66.1 \%$ & $88.8 \%$ & $61.5 \%$ \\
\hline $\begin{array}{l}\text { CA125 (>21 U/ml) or } \\
\text { sIL-2R } \alpha(>304.5 \mathrm{U} / \mathrm{ml})\end{array}$ & $97.3 \%$ & $36.6 \%$ & $96.2 \%$ & $34.6 \%$ \\
\hline $\begin{array}{l}\text { CA125 (>21 U/ml) or } \\
\text { sIL-2R } \alpha(>349.5 \mathrm{U} / \mathrm{ml})\end{array}$ & $97.3 \%$ & $54.9 \%$ & $96.2 \%$ & $53.8 \%$ \\
\hline $\begin{array}{l}\mathrm{CA} 125(>21 \mathrm{U} / \mathrm{ml}) \text { and } \\
\text { sIL-2R } \alpha(>304.5 \mathrm{U} / \mathrm{ml})\end{array}$ & $89.4 \%$ & $85.9 \%$ & $92.5 \%$ & $88.4 \%$ \\
\hline CA125 (>21 U/ml) and & $81.5 \%$ & $87.3 \%$ & $85.1 \%$ & $88.4 \%$ \\
\hline
\end{tabular}




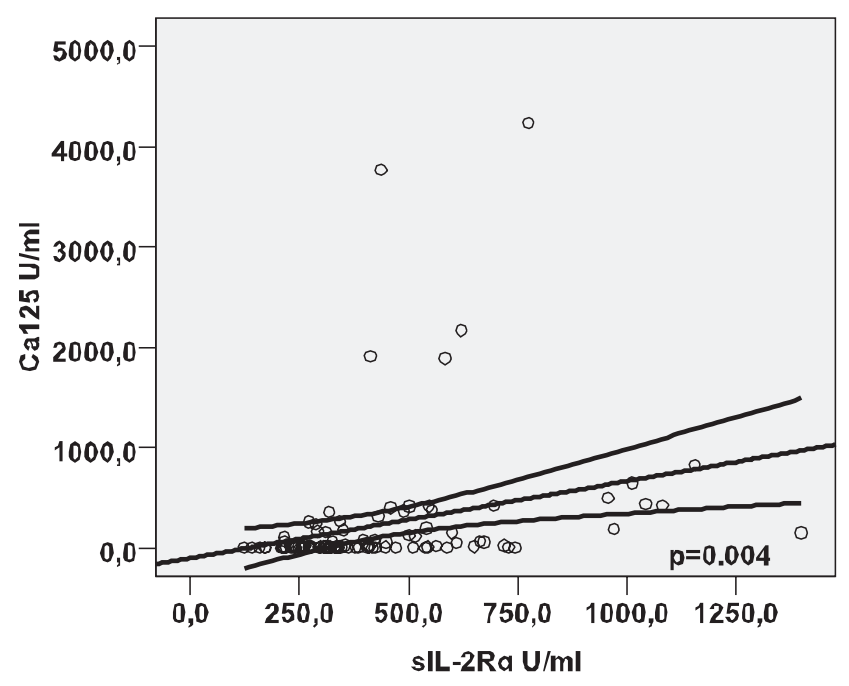

Fig. 2. Correlation between levels of Ca125 and sIL-2R $\alpha$ after patient exclusion with high serum concentrations (Ca125 $1000 \mathrm{U} / \mathrm{ml}$; sIL-2R $\alpha 1500$ $\mathrm{U} / \mathrm{ml}$ ) with $95 \%$ confidence interval of mean concentrations (Pearson Correlation, 2-tailed).

1993). This explains why only $35 \%$ cancer patients had elevated serum concentration of sIL- $2 \mathrm{R} \alpha$ in comparison to $86.2 \%$ when a threshold of $349.5 \mathrm{U} / \mathrm{ml}$ was applied. Another discrepancy is in calculation of the threshold using control group patients. Gebauer et al. suggested using the $95^{\text {th }}$ percentile, which is similar, but not exactly the same as the upper limit of the $95 \%$ of confidence interval of the mean control group serum concentration, which was used in our study.

To avoid mistakes that may arise from unequal distribution, extremely high concentrations were excluded from some calculations, but, even without exclusion of those ovarian cancer patients, serum sIL-2R $\alpha$ concentration was lower than in reports published previously $-828.7 \pm 135.3$ for all stages versus $1631 \pm 274$ and $2596 \pm 384 \mathrm{U} / \mathrm{ml}$ for stage I/II and stage III/IV epithelial ovarian cancer (Hurteau et al., 1995). Similarly, lower serum sIL-2R $\alpha$ concentrations among benign ovarian tumours were observed $-387.7 \pm$ 33.3 versus $1507 \pm 82 \mathrm{U} / \mathrm{ml}$ (Hurteau et al., 1995). The results from our study are similar to data published by Bruijn et al., in which ovarian cancer patients had higher serum levels of soluble interleukin-2 receptor alpha compared to patients with benign ovarian tumours or healthy blood donors (means of 750 vs. 469 and $390 \mathrm{U} / \mathrm{ml}$, respectively, $P<$ 0.001) (Bruijn et al., 1998). Our data resulted in higher diagnostic performance, because $86.2 \%$ and $92.1 \%$ of ovarian cancer patients had elevated serum sIL-2R $\alpha(>349.5 \mathrm{U} / \mathrm{ml})$ and $\mathrm{Ca} 125$ (> $21 \mathrm{U} / \mathrm{ml})$ concentrations, respectively, whereas in another study $79.6 \%$ and $77.8 \%$ patients with epithelial ovarian cancer had elevated serum levels of sIL-2R $\alpha(>$ or $=71 \mathrm{U} / \mathrm{ml})$ and CA $125(>$ or $=83 \mathrm{U} / \mathrm{ml})$, respectively (Ferdeghini et al., 1993).

$42.5 \%$ and $7.9 \%$ of patients with benign disease had also elevated serum levels of sIL-2R $\alpha$ (> $349.5 \mathrm{U} / \mathrm{ml})$ and Ca125 (> $21 \mathrm{U} / \mathrm{ml}$ ), which were significantly higher proportions than those in another report on raised serum levels of sIL-2R $\alpha$ and CA 125: 11.6 and 7.0\% of patients with benign ovarian diseases, respectively (Ferdeghini et al., 1993). Hurteau et al. reported elevated serum levels of either sIL-2R $\alpha$ or CA125 in eleven of 12 patients (92\%) with potentially curable stage I/II disease and elevations of both sIL-2R $\alpha$ and CA125 in 8 of $12(67 \%)$ (Hurteau et al., 1995). According to our study, a diagnostic algorithm using elevation of either sIL-2R $\alpha$ or CA125 had sensitivity of $97.3 \%$ with an unacceptably low specificity of $36.6 \%$ $54.9 \%$, depending on the cutoff level applied. The same algorithm was applied by Ferdeghini et al., who reported a sensitivity of $88.9 \%$, and the association of sIL-2R $\alpha$ and CA 125 had a specificity of $98.4 \%$ for epithelial ovarian cancer (Ferdeghini et al., 1993). In our population, performance of the diagnostic test showed similar high values, reaching sensitivity and specificity of $89.4 \%$ and $85.9 \%$, when elevated serum concentrations of sIL-2R $\alpha$ and CA 125 above $304.5 \mathrm{U} / \mathrm{ml}$ and $21 \mathrm{U} / \mathrm{ml}$ were applied at the same time. Another algorithm using simultaneously elevated biomarkers with a higher threshold for sIL-2R $\alpha$ (349.5 $\mathrm{U} / \mathrm{ml}$ ) had lower test sensitivity $(81.5 \%)$. In contrast, the specificity reported by Hurteau et al. was low for the combination of CA 125 and soluble IL-2R alpha, reaching $27.1 \%$ at sensitivity of $88.5 \%$, respectively (Hurteau et al., 1995). The wide differences in the values reported can be explained by the various threshold levels applied.

The high diagnostic ability of our diagnostic algorithm may be explained by homogeneity of the control group, as there were no patients with and elevated Ca125 concentration above $21 \mathrm{U} / \mathrm{ml}$. Moreover, even higher diagnostic performance was achieved when the same algorithm was applied for women at menopausal age, resulting in sensitivity and specificity of $92.5 \%$ and $88.4 \%$, respectively.

Ca125 had the largest area under the curve when compared to sIL-2R $\alpha$ or when both markers were combined. Also diagnostic sensitivity and specificity of Ca125 was higher when compared to sIL-2R $\alpha$ in a population consisting of both pre- and postmenopausal women $(92.1 \%$ and $76.0 \%)$ and also among menopausal women only $(92.5 \%$ and $80.7 \%$ ). However, specificity was lower when compared to the developed diagnostic algorithm that achieved sensitivity and specificity of $89.4 \%$ and $85.9 \%$ in a population consisting of both pre- and postmenopausal women and $92.5 \%$ and $88.4 \%$ in a menopausal women population.

A stronger correlation between Ca125 and sIL-2R $\alpha$ serum concentration was observed when the analysis was performed witout patient exclusion with high serum biomarker concentrations (Pearson correlation, 2-tailed; $32.3 \%$ vs. $28.0 \%$ ); both of the obtained correlations were statistically significant (Fig. 2). In two separate studies, correlation between serum Ca125 and sIL-2R $\alpha$ was not observed when evaluated in serum and ascitis (Hunter et al., 1990; Barton et al., 1993). The correlation in our study was weak, which may indicate the effect of other factors such as host immune responsiveness to tumour burden. Higher serum concentrations of sIL-2R $\alpha$ are associated with poor responsiveness to 
treatment, which obviously suggests the impact of immune response on the level of sIL-2R $\alpha$ (Lauria et al., 1992). Higher levels of sIL-2R $\alpha$ have been observed in malignant and autoimmune diseases, which may indicate impaired host immunity, but not tumour spread (Chilosi et al., 1987; Symons et al., 1988). Further evaluation of the proposed algorithm among other benign and malignant gynecological diseases is necessary.

In conclusion, addition of serum sIL-2R $\alpha$ level to ovarian cancer antigen CA125 levels improves ovarian cancer diagnostics. However, further prospective studies with larger sample sizes are required to confirm our findings.

\section{ACKNOWLEDGEMENTS}

The study was done within the framework of Latvian University project (number: 2009/0220/1DP/1.1.1.2.0/09/ APIA/VIAA/016) and Pauls Stradiňš University project (number: 2009/0147/1DP/1.1.2.1.2/09/IPIA/VIAA/009)

\section{REFERENCES}

Altman, A., Mustelin, T., Coggeshall, K.M. (1990). T lymphocyte activation: A biological model of signal transduction. Crit. Rev. Immunol., 10, 347-391.

Barton, D.P., Blanchard, D.K., Michelini-Norris, B., Nicosia, S.V., Cavanagh, D., Djeu, J.Y. (1993). High serum and ascitic soluble interleukin-2 receptor $\alpha$ levels in advanced epithelial ovarian cancer. Blood, 81(2), 424-429.

Bien, E., Rapala, M., Krawczyk, M., Balcerska, A. (2010). The serum levels of soluble interleukin-2 receptor alpha and lactate dehydrogenase but not of B2-microglobulin correlate with selected clinico-pathological prognostic factors and response to therapy in childhood soft tissue sarcomas. J. Cancer Res. Clin. Oncol., 136(2), 293-305.

Bruijn, H.W., ten Hoor, K.A., van der Zee, A.G. (1998). Serum and cystic fluid levels of soluble interleukin-2 receptor-alpha in patients with epithelial ovarian tumors are correlated. Tumour Biol., 19(3), 160-166.

Brunetti, G., Bossi, A., Baiardi, P., Jedrychowska, I., Pozzi, U., Bacchella, L., Bernardo, G. (1999). Soluble interleukin 2 receptor (sIL2R) in monitoring advanced lung cancer during chemotherapy. Lung Cancer, 23, 1-9.

Chilosi, M., Semenzato, G., Cetto, G., Ambrosetti, A., Fiore-Donati, L., Perona, G., Berton, G., Lestani, M., Scarpa, A., Agostini, C. (1987). Soluble interleukin-2 receptors in the sera of patients with hairy cell leukemia: Relationship with the effect of recombinant $\alpha$-interferon therapy on clinical parameters and natural killer in vitro activity. Blood, 70(5), 1530-1535.

Ferdeghini, M., Gadducci, A., Prontera, C., Malagnino, G., Fanucchi, A., Annicchiarico, C., Facchini, V., Bianchi, R. (1993). Serum soluble interleukin-2 receptor assay in epithelial ovarian cancer. Tumour Biol., 14(5), 303-309.

Gebauer, G., Rieger, M., Jäger, W., Lang, N. (1999). Prognostic relevance of soluble interleukin-2 receptors in patients with ovarian tumors. Anticancer Res.,19(4A), 2509-2511.
Hunter, V.J., Weinberg, J.B., Haney, A.F., Soper, J.T., Lavin, P., Metsch, L., Knapp, R.C., Bast, R.C. (1990). CA 125 in peritoneal fluid and serum from patients with benign gynecologic conditions and ovarian cancer. Gynecol Oncol., 36(2), 161-165.

Hurteau, J.A., Woolas, R.P., Jacobs, I.J., Oram, D.C., Kurman, C.C., Rubin, L.A., Nelson, D.L., Berchuck, A., Bast, R.C., Mills, G.B. (1995). Soluble interleukin-2 receptor alpha is elevated in sera of patients with benign ovarian neoplasms and epithelial ovarian cancer. Cancer, 76(9), 1615-1620.

Jo, S.A., Hwang, S.H., Chang, C.L., Kim, S.Y., Shin, H.J., Chung, J.S., Sol, M.Y., Lee, E.Y. (2010). Clinical relevance of elevated levels of serum soluble interleukin-2 receptor alpha (sIL-2R $\alpha$ ) in patients with non-Hodgkin's lymphoma. Korean J. Lab. Med., 30(6), 600-605.

Lauria, F., Rondelli, D., Raspadori, D., Zinzani, P.L., Benfenati, D., Pileri, S., Sabattini, E., Tura, S. (1992). Serum soluble interleukin-2 receptor levels in hairy cell leukemia: Correlation with clinical and hematological parameters and with alpha-interferon treatment. Leuk. Lymphoma, 7(1-2), 103-107.

Lissoni. P., Barni, S., Rovelli, F., Viviani, S., Maestroni, G.J., Conti, A., Tancini, G. (1990). The biological significance of soluble interleukin 2 receptors in solid tumors. Eur. J. Cancer, 26, 33-36.

Meyer, F., Samson, E., Douville, P., Duchesne, T., Liu, G., Bairati, I. (2010). Serum prognostic markers in head and neck cancer. Clin. Cancer Res., 16(3), 1008-1015.

Mills, G.B., Zhang, N., Schmandt, R., Fung, M., Greene ,W., Mellors, A., Hogg, D. (1991). Transmembrane signalling by interleukin-2. Biochem. Soc. Trans., 19, 277-285.

Owens, O.J., Taggart, C., Wilson, R., Walker, J.J., McKillop, J.H., Kennedy, J.H. (1993). Interleukin-2 receptor and ovarian cancer. Brit. J. Cancer, 68 , 364-367.

Pavlidis, N.A., Bairaktari, E., Kalef-Ezra, J., Nicolaides, C., Seferiadis, C., Fountzilas, G. (1995). Serum soluble interleukin-2 receptors in epithelial ovarian cancer patients. Int. J. Biol. Markers, 10(2), 75-80.

Rubin, L.A., Kurman, C.C., Fritz, M.E., Biddison, W.E., Boutin, B., Yarchoan, R., Nelson, D.L. (1985). Soluble interleukin-2 receptors are released from activated human lymphoid cells in vitro. J. Immunol., 135, 3172-3175.

Rubin, L.A., Nelson, D. (1990). The soluble interleukin-2 receptor: Biology, function and clinical application. Ann. Intern. Med., 113, 619-645.

Sedlaczek, P., Frydecka, I., Gabryś, M., Van Dalen, A., Einarsson, R., Harłozińska, A. (2002). Comparative analysis of CA125, tissue polypeptide specific antigen, and soluble interleukin-2 receptor $\alpha$ levels in sera, cyst, and ascitic fluids from patients with ovarian carcinoma. Cancer, 95, 1886-1893.

Smith, K.A. (1988). Interleukin-2: Inception, impact and implications. Science, 240(4856), 1169-1176.

Sperner-Unterweger, B., Neurauter, G., Klieber, M., Kurz, K., Meraner, V., Zeimet, A., Fuchs, D. (2011). Enhanced tryptophan degradation in patients with ovarian carcinoma correlates with several serum soluble immune activation markers. Immunobiology, 216(3), 296-301.

Symons, J.A., Wood, N.C., Di Giovine, F.S., Duff, G.W. (1988). Soluble IL2 receptor in rheumatoid arthritis. Correlation with disease activity, IL-I and IL-2 inhibition. J. Immunol., 141(8), 2612-2618.

Waldmann, T.A. (1991). The interleukin-2 receptor. J. Biol. Chem., 266, 2681-2684.

Received 18 October 2010 


\section{SERUMA ŠKIISTOŠĀ INTERLEIKĪNA 2 RECEPTORA ALFA (SIL-R2 $\alpha$ ) UN CA-125 KOMBINĒTAIS TESTS OLNİCU VĒŽA DIAGNOSTIKAI}

Olnīcu vēža diagnostiku var uzlabot, izmantojot kombinēto diagnostikas testu, kas sastāv no olnīcu vēža biomarkiera Ca125 un serumā šḳīstošā interleikīna 2 receptora alfa. Pētījuma mērkis bija novērtēt diagnostiskā testa precizitāti olnīcu vēža diagnostikā. Gadījumu kontroles pētījumā bija iesaistītas 38 pacientes ar olnīcu vēzi, 40 pacientes ar labdabīgu olnīcu audzēju un 31 vecumam atbilstošas veselas sievietes kontroles grupā. Ar olnīcu vēzi asociētā antigēna Ca-125 un serumā šḳīstošā interleikīna 2 receptora alfa koncentrācija tika noteikta, izmantojot standartizētu hemiluminiscences imunometriskās analīzes metodi. Kā robežvērtība biomarkierim Ca125 tika izmantota seruma koncentrācija $21 \mathrm{U} / \mathrm{ml}$, biomarķierim sIL-R2 $\alpha$ tika izmantoti divi robežlielumi — aprēḳinātā vidējā seruma koncentrācija un 95\% konfidences intervāla augšèjā robeža starp kontroles grupas sievietēm. Vidējā seruma koncentrācija olnīcu vēža pacientēm biomarkiieriem CA125 un sIL-2R $\alpha$ bija atbilstoši 265,9 $\pm 40,2 \mathrm{U} / \mathrm{ml}$ un $651,0 \pm 50,5 \mathrm{U} / \mathrm{ml}$. Diagnostiskā testa jutīgums un specifiskums sasniedza $89,4 \%$ un 85,9\%, kad CA125 tika kombinēts kopā ar sIL-2R $\alpha$ pie robežvērtības 304,5 U/ml ar nosacījumu, ka abām biomarķieru koncentrācijām serumā ir jābūt paaugstinātām. Menopauzē esošu sieviešu populācijā diagnostiskā testa jutīgums un specifiskums sasniedza $92.5 \%$ un 88,4\%. Serumā šḳistošā interleikīna 2 receptora alfa koncentrācijas noteikšanu serumā kopā ar biomarkiieri Ca125 var izmantot kā diagnostisko testu olnīcu vēža diferenciāldiagnostikai pie noteiktiem robežlielumiem, īpaši menopauzē esošu sieviešu populācijā. 